\title{
Film Cartridge Device
}

National Cancer Institute

\section{Source}

National Cancer Institute. Film Cartridge Device. NCI Thesaurus. Code C76119.

A device to hold an amount of film and facilitate its loading into a device. 